\title{
Mozaika „obrazư“ střední Evropy aneb problém výkladu a koncepce
}

\author{
Ivo Pospíšil (Brno)
}

Martin C. Putna: Obrazy z kulturních dějin Střední Evropy. Praha: Vyšehrad, 2018. 376 s.

ISBN 978-80-7429-977-3.

V první třetině 21. století se znovu objevují, a to s jakousi novou silou, knihy o střední Evropě. Jejich autoři se snaží tento fenomén jakoby znovu uchopit, aniž by př́liš dbali o návaznost na výzkumy osmdesátých a devadesátých let 20. století, o dřivějších výzkumech - až na výjimky, většinou ideologické povahy, nemluvě. Jejich základním znakem je pokus o jakési pozdní zachycení módního tématu: tak vznikají narychlo sestavené antologie dávno známých textů nebo sumarizování známých nebo méně známých, pro někoho zasutých fakt. $\mathrm{K}$ těmto pracím patř́i v dobrém slova smyslu také čtivá publikace Martina C. Putny, která je volným pokračováním jeho „obrazů“, pokaždé poněkud jiných, jež „mapuji““ čas a prostor určitých entit ${ }^{1}, \mathrm{i}$ když název někdy klame nebo přesně nepopisuje obsah, nebot' v př́ípadě prvních dvou asi nejde jen o religiozitu, pokud nepřipustíme, že veškeré lidské konání a kulturní úsilí je religiózní povahy. Koncepce „obrazů“, jimiž Putna navazuje na terminologii slavného spisu Havlíčkova, připomíná mozaiku jen málo spojitých textových celků, velmi čtivých, dobře napsaných, nasycených fakty, jmény a událostmi; horší už je to s postižením toho, co by mělo být vlastním cílem díla, pokud chce být původním. Připomíná mi proslulou pasáž z Cimrmanovy hry Posel světla: „Podívejte se, pane Ptáček, my vizionárí do tý budoucnosti vidí me, ale vidíme z ni jenom takový výjevy. Dám vám př̌klad. Vidim oheň. Hořri staveni, běhaji tam lidi s kbelikama. Co z toho můžu vyčist: že vyhořite. Že to

1 Viz jeho knihy Obrazy z kulturních dějin americké religiozity. Praha: Vyšehrad, 2010; Obrazy z kulturních dějin ruské religiozity. Praha: Vyšehrad, 2014. Viz naši rec.: Autoritationi obrazy Ruska jako vzorek českého prostoru a času (Martin C. Putna: Obrazy z kulturních dějin ruské religiozity. Praha: Vyšehrad, 2015). Novaja rusistika 8, 2015, č. 1, s. 48-61. zachvátí stodolu nebo chlívy, může poznat sousedy, co vám pomáhaji hasit, ale to je tak v̌sechno."

I tak je kniha jen volně skloubených „obrazů“ hodnotná a zaslouží si ocenění jako kadlub informací, kontextů, v nichž se prezentuje osobnost autora jako sebevědomého, vzdělaného, sečtělého hledače významových průniků, jindy zase jednostranného vykladače až příliš přesvědčeného, a hlavně usilovně přesvědčujícího, méně již přesvědčivě argumentujícího o své pravdě. Ale i to je součástí vědeckého bádání, ale pokud chce autor dojít k obecněji relevantním závěrům, musí vzít v úvahu i celkový koncept bádání o střední Evropě a zde pak již méně záleží na tom, zda se píše s velkým či malým „s“.

Jak autor sám deklaruje, oproti akcentaci času se zde manifestuje spíše prostor, tedy kulturní areál, ale je to tak jen zčásti, nebot nelze pomíjet ani jeho vývojovou dynamiku. Rozhodně nejde toliko o synchronní, spíše diachronní a evoluční pohled, tj. vektor času není eliminován. Obsah knihy odpovídá autorovým představám, co je střední Evropa: vychází navenek jen z několika pro něho preferovaných publikací a zcela opomíjí obrovskou literaturu, která byla za posledních 30-40 let vydána, nebo - jinak řečeno - čerpá z nich, ale nevíme přesně co a v jakém rozsahu. Volný výklad, jenž je autorovi vlastní, znemožňuje poznat, s čím z dosavadní literatury o střední Evropě souhlasí a s čím nikoli a proč a k jaké vlastní koncepci vlastně dochází. Takto to potom vypadá, že ke všemu dospěl jen vlastní četbou pramenné literatury, cestováním a že tyto odborné souvislosti nepotřebuje. Jinak řečeno, kniha se pohybuje po rovině horizontální, již méně vertikální, tedy jde doširoka a nikoli do hloubky: jinak by induktivně musela dojít k samostatnému pojetí střední Evropy, jímž by 
autor mohl reálně přispět nejen $\mathrm{k}$ sumarizaci materiálu, ale také k diskusím, jež se o předmětu jeho př́itomného zájmu stále vedou. ${ }^{2}$

Když pohlédneme na strukturu knížky a její jednotlivé kapitoly a začteme se do nich, je zřejmé, že zde najdeme silnější i slabší místa. Autor neváhal sebevědomě poznamenat, že „mu vyučeni ve slavistice a klasické filologii umožňuje př́stup $k$ textům ve všech středoevropsky relevantnich jazycích slovanských a románských" (s. 15; škoda že neuvedl ještě jména svých učitelů, jak se to obvykle činívá); němčina je ovšem samozřejmostí: o to více překvapuje, že právě německy psaných odborných textů uvedl poměrně málo. U německé stř̌ední Evropy se ještě zastavíme: autor ignoroval ten fakt, že koncept střední Evropy byl a do značné míry i dnes je silně ideologický, a to již od časů Svaté aliance, nemluvě o Friedrichu Naumannovi. Chybí mi tu postoj k pojmu „Ostmitteleuropa“ a k tomu, co na jedné konferenci právě o střední Evropě uvedl jeden německý kolega, a potvrdil tak všeobecně známý fakt: ve škole (po roce 1945) nás vždy učili, že střední Evropa je německý prostor. Takže svár o charakter toho, co je a co není střední Evropa pokračuje i dnes, tedy v době, kdy „matrice“ střední Evropy daná habsburskou monarchií navenek zmizela. Proto také někteří autoři dávají přednost pojmu „centrální“, a to i v němčině (Zentraleuropa), nebot pojem „Das Mitteleuropa“, jak zní ostatně název proslulé Naumannovy knihy, je už natrvalo spjat s jednoznačnou ideolo-

2 Viz práce Miloše Zelenky o střední Evropě, mj. studii Central Europe in Literary Studies. World Literature Studies 23, 2013, s. 14-28, a jeho knihu Stredni Evropa v souvislostech literárni a symbolické geografie. Nitra: Univerzita Konštantína Filozofa, 2008; k literatuře předmětu viz mj. také naše publikace, zejména: Středni Evropa a Slované (Problémy a osobnosti). Brno: Ústav slavistiky Filozofické fakulty Masarykovy univerzity, 2006; Areál a filologická studia. Brno: Masarykova univerzita, 2013; Central Europe: Substance and Concepts. Nitra: Constantine the Philosopher University in Nitra, Faculty of Central European Studies, 2015. Viz také svazky Středni Evropa včera a dnes: proměny koncepcí I. Kolektivní monografie. Ed. Ivo Pospísil. Brno: Jan Sojnek - nakladatelství Galium, 2015; Středni Evropa včera a dnes: proměny koncepci II. Kolektivní monografie. Ed. Ivo Pospísil. Středoevropské centrum slovanských studií ve spolupráci s Ústavem slavistiky FF MU, Českou asociací slavistů a Slavistickou společností Franka Wollmana. Brno: Jan Sojnek-Galium, 2018. gií, byt její autor, který zemřel roku 1919 (kniha vyšla 1915), byl později chápán spíše jako liberál než jako nacionalista a jeho jméno nese i stipendium spjaté s německými liberály z FDP. I spor o charakter a význam jeho knihy tedy pokračuje. To nic nemění na přínosnosti knihy a jejím důkladném materiálovém základě. Takže: tam, kde je antika a středověk, je autor suverénní, ale ani zde se nedotýká všeho důležitého; pochopitelně věci religiózní, katolické jsou jeho silnou stránkou, slabší je to v prrípadě široké slavistiky, ale jsem také slavista a vím, jak je těžké vše postihnout, nebot specialisté na určitá témata je znají podrobněji a hlubinně: o to více si cením autorovy odvahy se do těchto složitostí pouštět a nahlédnout je z jiných zorných úhlů, pojmout je s určitými posuny důrazu: co jiného lze ostatně v našich „vědách“ objevit? Nejpřesvědčivější je autor tam, kde pojednal o věcech přece jen umně exploatovaných, a hlavně nepř́liš módních (např. Solnohradsko a K. H. Waggerl, zajímavý pohled na Prešerna a Plečnika, podobně na Slováky, resp. na Horní Uhry, na Sedmihradsko, problém islámu a Bosny), i když takřka ke všemu lze vznést připomínky nebo výhrady. Tam, kde jde o módnější a často exploatovaná témata, je už pomíjení relevantní literatury citelnější a je vidět: to se týká Slezska a Angela Silesia (když si pomyslím na "stohy“ prací jen polské a německé provenience z posledních třicet let), Dalmácie, Rilka, Celana, Sedmihradska a Ference Dávida, Iva Andriće. Často mi doslova zatrne, když tu nenacházím některá klíčová jména, např. Elemera Hantose, autora série knih, jež pokryly v podstatě všechny problémy střední Evropy, o němž jsem v devadesátých letech vícekrát psal a později mu věnoval knihu o středoevropském hnutí s centrem v Brně v meziválečném období brněnský historik, etnolog a hungarista Miroslav Jeřábek. ${ }^{3}$ Dále ov-

3 Viz naše výše uvedené publikace a desítky samostatných studií včetně Slovanstvi a středni Europa. In: HRODEK, Dominik a kol.: Slovanství ve středoevropském prostoru. Iluze, deziluze a realita. Pardubická konference (22-24. 4. 2004). Praha: LIBRI, 2004, s. 23-35; edici tří svazků s vídeňskou slavistikou: Litteraria Humanitas XI. Crossroads of Cultures: Central Europe, Kreuzwege der Kulturen: Mitteleuropa, Křižovatky kultury: Středni Evropa, Perekrest- 
šem celé svazky rakouských výzkumů, polských, mad’arských, anglických, chybí tu René Wellek a knihy, kde se o něm píše i ve spojitosti se střední Evropou, to se nedá omluvit ani technicky ani záměrem. Takto se kniha stává spíše popularizujícím čtením, kterým asi chce být, i když mohla rozkročena plnit jak funkci vědeckou, tak popularizační. Stř̌ední Evropa se v nové době, přibližně od osmdesátých let minulého věku zkoumala v různých centrech - kromě Vídně to byla Budapešt, mad’arské a polské univerzity (mj. Pilíscsaba, Poznaň), Německo, významná publikace byla vydána v Kodani; o všem podstatném jsme psali v četných studiích a edicích. I publikace, jež autor nepovažuje za důležité nebo které chce $\mathrm{z}$ různých důvodů ignorovat, hrají v poznání objektu výzkumu nějakou roli, s níž by se měl argumentačně vyrovnat. Podnětná je například pasáž o „české říši“; je zde hodně dobrých úvah a spojitostí, ale nutno asi obezřetněji rozlišovat, a to i zde, mezi zemským a národním principem, mezi tzv. Čechií, jak s ní autor operuje (tento detail už raději ani nebudu komentovat), Čechami, Bohemií, Böhmen atd., což je však notoricky známo. Ono tíhnutí Čechů k slovanství, jež nyní někomu vadí, lze vysvětlovat všelijak: Zdeněk Mathauser kdysi uváděl jako důvod potřebu komplementarity, nutnost nějak jakoby nehotový celek doplnit (česko-slovanský, česko-slovenský, česko-moravský apod.), potřeba „druhých vlajek“, které vždy vedle vlastní národní nebo státní u nás rády vlály, a vznikaly kolem toho pravidelné spory. Na několika místech Putna píše o české expanzi na Východ (myslí ovšem expanzi duchovní, nikoli vojenskou, ale severovýchodní směr byl blízký i českým vojskům, to nutno připustit, i když zcela

ki kul'tury: Srednjaja Jevropa. Brno: Masarykova univerzita, Filozofická fakulta, Ústav slavistiky, 2002. Ed. Ivo Pospísil; Comparative Cultural Studies in Central Europe. Eds. Ivo Pospísil (Brno) - Michael Moser (Wien). Brno: Ústav slavistiky Filozofické fakulty Masarykovy univerzity v Brně, 2004; Litteraria Humanitas XIII. Austrian, Czech and Slovak Slavonic Studies in Their Central European Context. Eds. Ivo Pospíšil - Michael Moser - Stefan M. Newerkla. Brno: Ústav slavistiky Filozofické fakulty Masarykovy univerzity, 2005; JEŘÁBEK, Miroslav: Za silnou středni Evropu: středoevropské hnutí mezi Budapeští, Vídni a Brnem v letech 1925-1939. Praha: Dokořán, 2008. vypustíme misi československých legií). Nicméně zůstává tu dvojí češství, mýtus babičky; jen se mi zdá, že ta kontaminace v celek, v němž vedle sebe stojí sv. Ludmila, Božena Němcová s Babičkou, Magdalena Dobromila Rettigová, Ladislav Smoljak a Zdeněk Svěrák, mariánský kult nebo Adam Václav Michna z Otradovic je snad až příliš odvážná, ale i tak je hodna respektu. Horší je to s kapitolou o Moravě, i když jsem s radostí četl partie o Moravě obecně a západní Moravě zvláště a spojitosti katolických a komunistických autorů (byt si o důvodech jejich blízkosti myslím něco zcela jiného), které nutkavě připomínají mé vlastní dávnější i novější studie. ${ }^{4}$ Ale aby na problém Moravy a Brna bylo na nahlíženo racionálně a věcně - $\mathrm{k}$ tomu je ještě daleko.

Partie o Slezsku je také poměrně slabší, na druhé straně je kvalitní „obraz“ Horních a Dolních Rakous; velmi dobré jsou části, v nichž se autor snaží organicky pojednat o židovství a jeho klíčové poloze v středoevropském areálu. Obecně rakouské země se podařily včetně Korutan a Štýrska, stejně jako Tyroly a Voralbersko, kde se mu v podstatě všude propojuje s italsko-francouzským okruhem, s renesancí

4 Existuje moravská literárněvědná rusistika a ukrajinisti$k a$ ? In: Morava a české národní vědomí od středověku po dnešek. Brno: Matice moravská, 2001, s. 153-172; K některým aspektům morauské rusistiky. In: Rusové a Morava. Russkije i Moravija. Sborník referátů a sdělení z konference 13. 1. 2007. Brno: Ruské kulturně osvětové sdružení na Moravě ve spolupráci s Ústavem slavistiky Filozofické fakulty Masarykovy univerzity, Obcí moravských spisovatelů, Českou asociací slavistů a Slavistickou společností Franka Wollmana. 2007, s. 24-35; The Park-Garden Emblem and Alternatives of Literary Evolution (between England, Russia and Moravia). In: Space of a Garden - Space of Culture. Edited by Grzegorz Gazda and Mariusz Gołąb. Cambridge Scholars Publishing, 2008, s. 91-104; Pavol Strauss a hrst českých souvislostí. In: Pavol Strauss a katolícka moderna. Ed. Ján Gallik. Nitra: Ústav stredoeurópskych jazykov a kultúr, Fakulta stredoeurópskych štúdií, Univerzita Konštantína Filozofa, 2014, s. 91-109; K metodologii ekfrasisa: ekfrasis $i$ arealnyj kontekst (kejs-stadi o poezii i proze areala zapadnoj Moravii). In: Teorija i istorija ekfrasisa: itogi i perspektivy izučenija. Kollektivnaja monografija pod naučnoj redakciej Tatjany Avtuchovič při učastii Romana Mnicha i Tatjany Bovsunovskoj. Siedlce: Institut regionaĺnoj kultury i literaturovedčeskich issledovanij imeni Franciška Karpińskogo v Sedl'cach, Kijevskij nacionaĺnyj universitet imeni Tarasa Ševčenko, Grodnenskij gosudarstvennyj universitet imeni Janki Kupaly, 2018, s. 103-114. 
a antikou. I když studie z oblasti jihoslovanské, když k nim připočítáme i teritorium dnešního Slovinska, tedy Kraňsko, pomezní Furlánsko, kde se kř́žzi tradice rakouská, židovsko-italská a slovinská, mají k dokonalosti dále, najdeme tu zajímavé úvahy, jež svědčí o tom, že je autor zná z autopsie; podobně zajímavá je partie o Uhrách s case study o Péteru Esterházym a katolické postmoderně. Mé sympatie má i výklad o horních Uhrách, tedy víceméně o dnešním slovenském kulturním prostoru a areálu dnešního Slovenska, i když by někteří Slováci asi hodně namítali, a o Sedmihradsku viděném v dimenzi reformační, zatímco Charvátsko/ Chorvatsko, Dalmácie (přesně ukázal na složité dějiny dnešního „velkého Chorvatska“) a Haliče stojí přece jen poněkud ve stínu, nebot’ jde o témata hojně probíraná, včetně postavy Bruna Schulze, o němž bylo, hlavně Němci a Poláky, ale i jinými, napsáno opravdu mnoho. Obraz Bukoviny je atraktivní: škoda, že se autor nezmiňuje také o jiných autorech, např. o ukrajinsko-německém básníkovi Juriji Fed’kovyčovi a jeho českém znalci.

Další kladnou vlastností „obrazů“ je schopnost pohybovat se na hraně národních, náboženských a kulturních areálů, nebot’ o tom střední Evropa vlastně je: Putna tak implicitně postihl její ráz.

Kdybychom měli odpovědět na tradiční otázku, co je minimalistické a maximalistické pojetí střední Evropy, museli bychom podobně jako autor vyjít $\mathrm{z}$ historicky utvářeného teritoria habsburské říše s tím, že středoevropskost jejích území tu slábla, tu sílila, jak příslušná území přestávala být součástí ř́š́e a stávalo se tu Itálií, jindy Jugoslávií apod. Z tohoto hlediska mi v „obrazech“ chybí Bavorsko a Sasko, i když byly $\mathrm{s}$ říší spojeny volněji - důvody jsou známé. Dál už si spekulovat nedovolím.

Hlavní problém, k němuž se kniha několikrát vrací, je místo střední Evropy v Evropě; autor tu zase probírá dilema Východu a Západu, které je natolik zatížené, že je podle mého soudu ani nelze kognitivně využít. Jestliže je střední Evropa vlastně hodnotový Západ, proč se jí říká střední? A představa, jak stř̌ední Evropa expan- duje na Východ a vyváží tam „západní“ hodnoty? Není to také naopak? Území dnešního Běloruska a Ukrajiny, nazývané někdy západní Rus (ale není v tom nic rusofilského, jde prostě o význam slov „Rus“, který se po staletí měnil), bylo oním mostem nebo nástupním prostorem, odkud na Východ proudila renesance, humanismus (kromě trasy Itálie - Byzanc) a hlavně baro$\mathrm{ko}^{5}$, ale Rusko Petrových reforem právě střední Evropu vynechalo a šlo př́mo na nejzazší sever a západ: proto se tak do sebe liší ukrajinská, běloruská a ruská literatura (a nakonec i česká) literatura 19. a 20. století. Ostatně Rusko střední Evropu sice zasahuje, ale také ji ignoruje, dívajíc se se dál do Evropy a za její horizonty, asi v duchu své imperiální představy, ale to vše tu zanechává stopy. Nelze jen hledat vybrané minulostní stopy, jsou i stopy, které se nemusí líbit, ale ty všechny tu zůstávají a zůstanou: tedy i střední Evropa vklíněná v soukolí Německa a Ruska, Východu a Západu, Severu a Jihu, Balkánu a Mediteránu, tyto stopy zůstávají, jak se dějiny dějí. Nemyslím si, že ze střední Evropy šly ze Západu na Východ jen pozitivní poselství, že „po tomto mostě kráčela ze Západu na Východ moderni civilizace, nesouci myšlenky tolerance a svobody, individuálni zodpovědnosti a občanské společnosti." (s. 328-329), to bychom museli mít velmi výběrovou pamět a nejde pouze o její občasné padání. Je tedy přítomná kniha čtivým svědectvím o hledání středoevropskosti, řekl bych čtivým bádáním naplněným fakty a souvislostmi, výborná jako inteligentní, netradiční, netuctová, nadstandardní učebnice. Autorovo pojetí střední Evropy si tak čtenář musí vytvořit z „obrazů“ sám a autor mu v průběhu pomáhá a v závěru to shrne. I když se zdá, že autor ponechává čtenáři hodně svobody, řada míst nás přesvědčuje o opaku (viz výše). To je jeden z rozporů kni-

5 LAPPO-DANILEVSKIJ, Aleksandr: Politische Ideen in Rußland des 18. Jahrhunderts. Istorija političeskich idej v Rossii $v$ XVIII veke v svjazi s obščm chodom razvitix kultury $i$ politiki. Bausteine zur slavischen Philologie und Kulturgeschichte, Neue Folge, Bd. 1. Predislovije M. Ju. Sorokinoj. Podgotovka teksta M. Ju. Sorokinoj pri učastii K. Ju. Lappo-Danilevskogo. Köln - Weimar - Wien: Böhlau Verlag, 2005), viz naši recenzi: Potřebná edice o ruském myšleni. Slavica litteraria, X 9, 2006, s. 326-327. 
hy; hledání specifika střední Evropy, přičemž se její role nakonec svádí k jakési „západní“ misi směrem na Východ. Tím se poněkud stírá ta barevnost, pluralita, juxtapozičnost, jimiž hýří vlastní „obrazy“ vycházející z konkrétních dat a nikoli z apriorních tezí. Problémem knihy je tak rozpor mezi povahou výkladu a vykládanou koncepcí. Nicméně barvité „obrazy“ zůstávají a s nimi i možnost dotváření reálné střední Evropy, o níž nejednou psali, že je o to stabilnější, oč je mlhavější a ambivalentnější. Cesta $\mathrm{k}$ veri- fikaci toho, co dnes představuje komplex střední Evropy, vede přes skromnou, systematickou, detailní analýzu i minuciózních detailů, nebot právě z nich se skládá tento rozporuplný, diachronní i synchronní celek. Toto shromažd’ování nebude ještě dlouho ukončeno, pokud někdy vůbec, ale nemůže být ignorováno.

Ke všem recenzovaným knihám přistupuji kriticky, ale sine ira et studio a hledám v nich hlavně věci pozitivní, přínosy, nové věci. Těch v této knize - nehledě na výše uvedené - najdeme dost.

prof. PhDr. Ivo Pospišil, DrSc.

Ústav slavistiky

Filozofická fakulta, Masarykova univerzita

Arna Nováka 1, 60200 Brno, Česká republika

ivo.pospisil@phil.muni.cz 